\title{
Using a sensitive luciferase immunoprecipitation system (LIPS) to detect HTLV-I/II seroindeterminates in Jamaica
}

\author{
Yoshimi Akahata', Anna Abrams', Elizabeth Maloney², Matthew McCormick', Steven Jacobson ${ }^{1 *}$ \\ From 15th International Conference on Human Retroviruses: HTLV and Related Viruses \\ Leuven and Gembloux, Belgium. 5-8 June 2011
}

Human T-cell Leukemia Virus type I (HTLV-I) infects an estimated 15-20 million persons worldwide. A number of diseases have been associated with this virus including adult T-cell leukemia/lymphoma (ATLL), HTLV-associated myelopathy/tropical spastic paraparesis (HAM/TSP), HLTV-I uveitis, and HTLV-I-associated infective dermatitis. The screening process for HTLV-I among blood banks includes detection by an enzyme immunoassay (EIA) followed by a confirmatory western blot (WB). Seropositive results are defined by the presence of all core bands (p19, p24, and p53) as well as the band specific for recombinant HTLV-I Env glycoprotein. However, numerous cases have been documented in which a positive response was detected by ELISA, but WB displayed an incomplete banding pattern. These samples were then categorized as seroindeterminates. Using the LIPS assay, $60 \%$ of the 53 seroindeterminate samples previously screened by ELISA and WB displayed anti-HTLV-I Gag, Env or Tax antibody responses (based on 2 standard deviations above the mean value for the HTLV-I negative group). The LIPS assay was also able to detect anti-HTLV-I antibody responses in $6 \%$ of the 167 samples determined to be HTLV-I ELISA negative. A number of these samples were subsequently found to have an indeterminate WB pattern. Although the significance of these HTLV-I/ II seroindeterminates is unclear, it may suggest a much higher prevalence of exposure to HTLV-I/II than previously estimated, as seroindeterminate samples may indicate exposure to the virus. The LIPS assay is a sensitive and high throughput antibody detection assay which

\footnotetext{
* Correspondence: jacobsons@ninds.nih.gov

${ }^{1}$ Neuroimmunology Branch, National Institute of Neurological Diseases and Stroke, National Institutes of Health, Bethesda, MD, USA

Full list of author information is available at the end of the article
}

may prove to be a useful tool in HTLV-I related clinical investigations.

\section{Author details \\ ${ }^{1}$ Neuroimmunology Branch, National Institute of Neurological Diseases and Stroke, National Institutes of Health, Bethesda, MD, USA. ${ }^{2}$ Division of Epidemiology, Food and Drug Administration, Silver Spring, MD, USA.}

Published: 6 June 2011

doi:10.1186/1742-4690-8-S1-A249

Cite this article as: Akahata et al.: Using a sensitive luciferase

immunoprecipitation system (LIPS) to detect HTLV-I/II

seroindeterminates in Jamaica. Retrovirology 2011 8(Suppl 1):A249.
Submit your next manuscript to BioMed Central and take full advantage of:

- Convenient online submission

- Thorough peer review

- No space constraints or color figure charges

- Immediate publication on acceptance

- Inclusion in PubMed, CAS, Scopus and Google Scholar

- Research which is freely available for redistribution

Submit your manuscript at www.biomedcentral.com/submit
() Biomed Central 